\title{
Creating Catch 22: zooming in and zooming out on the discursive constructions of teachers in a news article
}

Jayne Keogh* and Barbara Garrick

Education and Professional Studies, Griffith University, Gold Coast Campus, Gold

Coast, Queensland, Q4222, Australia

(Received 5 October 2008; final version received 9 November 2010)

*Corresponding author. Email: j.keogh@griffith.edu.au

<abstract>

The media regularly present negative news articles about teachers and teaching. This paper focuses particularly on one such news article. Using reflective analytic practices, first we zoom in to conduct a detailed analysis of the text. We find that complex and contradictory moral categories of teachers are assembled within and through the text. We then zoom out to consider the potentially detrimental effects of such public discourses on teachers and the teaching profession. We make visible the dominant discourses in this text, illuminating some of the societal issues and practices that are textually constituted within this and other news articles about teachers. We provide evidence of a public discourse that might be contributing towards continuing concerns and negative public opinion regarding teacher quality and schooling standards. We argue that such news articles may well work to influence public opinion regarding declining teacher quality and standards, and of public schools as being in crisis, creating moral panic.

Keywords: textual analysis; teachers; media; reflective practice; public discourses 
"Sure there's a catch," Doc Daneeka replied. "Catch-22. Anyone who wants to get out of combat duty isn't really crazy".

There was only one catch and that was Catch-22, which specified that a concern for one's own safety in the face of dangers that were real and immediate was the process of a rational mind. ... Orr was crazy and could be grounded. All he had to do was ask; and as soon as he did, he would no longer be crazy and would have to fly more missions. Orr would be crazy to fly more missions and sane if he didn't, but if he was sane he had to fly them. If he flew them he was crazy and didn't have to; but if he didn't want to he was sane and had to. Yossarian was moved very deeply by the absolute simplicity of this clause Catch-22 and let out a respectful whistle.

“That's some catch, that Catch-22”. (Heller 1955, 54) @ 1955

\section{Introduction and rationale}

Media representations of teachers and teaching throughout the western world offer repeated negative images of students and teachers, "generating a crisis mentality towards education" (Thomas 2006, 24). This paper takes a focused analytic interest in the nature and extent of the images of teachers portrayed in media news and feature articles, considering their potential impact on public opinion regarding teacher quality and practice. We trace an analytic journey through one particular news article about a proposed payout to teachers deemed to be "sub standard" that was published in a major Australian newspaper on 25 April 2002 (Fynes-Clinton 2002), documenting our on-going critical reflections. First we describe the socio-historical context in which this particular news article appeared and discuss the notion of media as public discourse. We then describe the critically reflective analytic approach we used to analyse the text before "zooming in" (Risner 2002) to analyse, in detail, some of the 
complex moral versions of teachers that were constructed within this text. We then "zoom out" from the text (Risner 2002) to situate the discussion within public discourses regarding teacher quality in Australia. Using these critically reflective approaches, we show that multiple and often implicitly contradictory moral versions of teachers are constructed discursively in media items. The potential impact of negative media constructions on continuing public opinion regarding teacher quality and schooling practice in this and other western nations suggests that such images may well work to perpetuate a moral panic (cf. Cohen 1980) regarding education in contemporary society.

\section{Setting the scene within historical context}

Concerns regarding teacher quality are not new, having been a feature of education policy for well over 20 years. In Australia, in 1988, a Ministerial Statement titled Strengthening Australia's Schools (Dawkins 1988) added a new dimension to the issue, when quality was assessed "in terms of the process of national microeconomic reform" (Thomas 2006, 18). Schools were viewed as playing a critical role in the nation's economy, and reform was to take the form of "continually look[ing] for ways to improve the quality, relevance and effectiveness of schools throughout Australia" (Dawkins 1988, foreword). Teachers were positioned as critical in the process of educational reform. A positions paper published by The Schools Council in Australia in 1990 confirmed the centrality and national importance of quality teachers and teaching for this reform process.

In 2000, a Commonwealth Report published by the Department of Employment, Education, Training and Youth Affairs stated that "education of the highest quality requires teachers of the highest quality" (DEETYA 2000, 3). This 
Report included recommendations for a program directed towards improved teacher quality, allocating funding for the development of sets of teaching standards by the various state teacher registration boards and associations. A deficit view of teacher quality was central to the program outlined in this report that stressed the need to raise student standards, identifying teachers as the cause of these poor standards.

According to Ball, "media coverage of education is primarily about 'blaming"" (2008, 110). In Australia, media articles present negative views of teachers and teaching regularly. Lewis suggests that "overt teacher-bashing" $(1991,10)$ is a dominant stance in the media. This negative media thrust was confirmed officially in 1997 in the Australian Ministerial Advisory Council on the Quality of Teaching Report (MACQT), where it was stated that:

dedicated educators in our schools receive little public praise ... for their efforts. Regularly, writers report on the major problems of the teaching profession: how education is letting the country down, how unions are undermining schools, how there is a flagging of the spirit and a loss in morale. $(1997,1)$

Despite evidence to the contrary, such as that included in the Australian Parliamentary House of Representatives Standing Committee Report Top of the Class: Report on the Inquiry into Teacher Education on Education and Vocational Training (2007) statement that there was no crisis in teacher education or teacher quality, deficit public discourses regarding teacher quality persist as an underlying sub-theme in more recent and current state-based policy documents, national directives, and media articles. Such texts are viewed as public discourses. 


\section{Media as public discourse}

Texts, including news articles, actively convey various meanings through the use of discourses. The term discourse is used here to denote the different types of language used in different sorts of social situations that are subject to particular conventions and call into being particular versions of the social world (Fairclough 1992). Discourse, then, is a "type of language associated with a particular representation, from a specific point of view, of some social practice" (Fairclough 1995, 41). Textual discourses do more than merely convey information; they also convey aspects of the identities and relations of writers and readers, about the writers, about their audiences, and about people and various topics (Keogh 1999). Discourses construct particular categorical identities as well as providing possibilities for alternative identities and ways of being. Professional identities can be both shaped and constrained within particular discursive fields constructed through many discourses (Thomas 2008). As such, discourses work as positioning practices, defining individuals as "something like 'made to seem to be a certain type of person', or 'given a particular identity'” (Ivanic 1994, 4).

This paper is underpinned by the notion that media have a role in constructing dominant ideological understandings of reality and in moulding public opinion (Thomas 2009). Government policy directives and news articles are public textual discourses. Public textual discourses refer to "that order of social relations mediated by texts which is otherwise identified by such terms as 'public opinion', 'mass communications', and the like" (Smith 1990, 123). They are the vehicles through which public opinion is formed (Habermas 1996), being part of the public sphere that works as a social and political category for unity and coherence, excluding oppositional voices and practices (Thomas 2002). News articles construct dominant discourses and preferred readings, generally based on commonsense, taken-for-granted 
assumptions about what is "typical" or "normal" (Gee 1999, 59). Dominant cultural assumptions and ideological understandings are coded into media texts, although there is always a possibility of texts being read in multiple ways, and of being accepted or contested by different readers (Johnson 2001). By documenting how public discourses construct particular social categorisations and the relationships between such categorisations, it is possible to reveal how they work to articulate and structure the everyday world, revealing ideologies largely hidden within such texts. It is with such a view of texts and discourses that we came to analyse the newspaper article under consideration.

\section{The analytic approach and method}

The analytic approach adopted for the purposes of this paper is institutional ethnography (Smith 2005). Underlying analysis is the notion that texts actively construct and reflect the social world of which they are a part. According to Smith, "textually mediated discourse is a distinctive feature of contemporary society existing as socially organized communicative and interpretive practices intersecting with and structuring people's everyday worlds" (1990, 162-3).

Texts work as active constituents of social relations (Baker 2000), and organise particular courses of concerted social action (Heritage 1984). The operative part of the social action in the text must be reader activated. The text is, thus, dependent on readers' interpretive practices. Institutional ethnography recognises the particular ways in which texts enter into social action and work as coordinators of socially organised processes, enabling analysts to investigate the macrosocial ethnographically (Smith 2005). Analysis of any active text depends, therefore, on the analyst-as-member's social knowledge of the interpretive practices and schemata relevant to the reading (Smith 1990). 
The analytic perspective adopted here is that of an insider's standpoint. Indeed, "a separation between researcher-qua-researcher and researcher-qua-member is not possible" (McHoul 1982, 88). This standpoint "addresses from within the actual work of coordination, the on-going co-ordering that brings into being, that $i s$, the social" (Smith 1990, 9). As part of our role as teacher educators we, as authors of this paper, have taken a continuing interest in news articles about teachers, schools and educational issues. We also have been secondary school teachers, each with well over twenty years of school-based classroom experience. We thus interrogate the text positioned as analytic "insiders", bringing our prior knowledges of the social organisational arrangements and practices of teachers. These positions both inform and inhibit our interrogation of the data.

Analysis was informed by an ethnomethodological approach that investigated how particular social categories and structures were actively articulated within and through this text (Hester and Eglin 1997, 157). The textual construction of categories and categorisation can be opened for critical examination to show how they "work to lock discourses into place" (Baker 2000, 99). Working through the text, we first detailed the ways in which the news article actively assembled particular versions of the different categories of 'teacher'. Each version inferred particular commonsense understandings of being a teacher. These textual constructions were, implicitly, moral versions of particular teacher-types. According to Jayyusi (1984, 2), “categorization work is embedded in a moral order ... [and] the social order is a moral one" (emphasis in original). Some categories were used and could be read commonsensically as going together, such as "good teacher" / "bad teacher". Such associations are known as "standardised relational pairs" (Silverman 1993, 111-12). The standardised relational pairs of teachers were constructed in an on-going way throughout the text that is the 
focus of this paper, both explicitly and implicitly, in the form of binary oppositions. These contrasting and often contradictory moral versions of the teacher categories were complex and sometimes contradictory. As a consequence we, the analysts, were unable to read ourselves comfortably into the different versions, as described below.

Our readings of ourselves were informed by critical reflective practice, the vehicle used as an intervention to expose the tensions in our reactions towards the news article. Reflective practice can be both intellectual and affective, and reconstruction of events, through critical reflection, can create altered perspectives, with "the potential to facilitate transformed practice" (Stockhausen and Kawashima 2002, 118).

We used the reflective practices of zooming in and zooming out to analyse the news article that is the focus of this paper. First we zoom in to conduct a detailed analysis of the text. Zooming in is the process of "looking underneath and in between the lines of the narrative" for particularity (Risner 2002, 8). By using methods derived from membership categorisation analysis (MCA) to locate "culture in action" (Baker 2000), we document the text's use of binary oppositional categories in ways that worked to privilege 'new teachers' and to devalue 'experienced teachers' as contrast structures. We then zoom out of the text to consider how it was situated within its larger socio-historical context. Zooming out: "allows each narrative reflection to speak again, not merely on a purely personal level, but more broadly in dialogue with critical theories for emancipatory change and post positivist concerns for humanising social practice" (Risner 2002, 8). Using these critically reflective analytic approaches, we reveal a particular public discourse that, to some extent, contributes to generating the continuing media-led crisis mentality regarding education and teachers in Australia identified by Thomas (2006). 


\section{Analysis and discussion}

In 2002, the Queensland Minister of Education at that time announced a proposed $\$ 50,000$ payout to each experienced teacher deemed to be incompetent as an incentive to leave the state (public) school system. The announcement was published in a the front page article on 25 April 2002 (ANZAC Day $^{1}$ ) in The Courier Mail, the leading daily newspaper published in Queensland, Australia, by Newscorp (Fynes-Clinton 2002). The headline "Cash lures to smarten up teaching" immediately activated extremely negative initial responses in us as reader-researcher-analysts. As members of the teaching profession, and also as members of one of the age/experience teacher categories being written about, we both were drawn to the article. As sociological analysts, we were provoked, independently, by the article, viewing it as a challenge to our positioning as experienced teachers who possibly might be considering or in need of a "career change" (Fynes-Clinton 2002). We reflected on why the article generated such negative reactions from us, and decided to address our concerns in the form of this paper. In this way we would bring to the surface our "ways of being and acting during or after [this] ... event" (Stockhausen and Kawashima 2002, 118). As such, the news article was the stimulus that triggered the analytic process.

The news article reflected a commonsense premise that classrooms were in need of re-invigoration, and that teachers and teaching in Queensland needed "smartening up". The solution to the "problem" was a $\$ 50,000$ cash incentive to be used as a payout to encourage 'underperforming' teachers to leave the state school system. An initial scan of the article revealed what at first appeared to be a simple binary of "highly motivated [beginning teacher] graduates" in contrast to experienced

\footnotetext{
${ }^{1}$ ANZAC Day is a public holiday in Australia and New Zealand, commemorating the troops of the Australian and New Zealand Army Corps that took part in the two World Wars.
} 
but "disenchanted teachers" (Fynes-Clinton 2002). The article seemed to present a simplistic uni-dimensional blame-the-victim image of teachers that did nothing to problematise this view or suggest the need to question conditions pertaining to teacher employment and workplace practices in the state education system that might be contributing to this situation.

Although the article seemed at the outset to construct an essentialist and commonsense teacher binary, further sociolinguistic analysis revealed a more complex range of discursive constructions of teacher-types. As such, our minds traversed between what we thought we knew and what was occurring in the text (Stockhausen and Kawashima 2002). Detailed textual analysis made it clear that neither the message nor the audience it addressed were obvious. The article seemed to suggest that particular teachers were to self-select themselves as incompetent by addressing unnamed but key criteria in a competent manner. However, such competence might well have been viewed by the Education Department as a reason for not enabling such self-selected 'incompetent' teachers to be accepted within that teacher category. That the article was published on Anzac Day reminded us, inter-textually, of Catch-22 (Heller 1955).

\section{Zooming in (an intimate reading)}

Detailed analysis commenced by zooming in to identify and critique the details of the textual constructions that possibly contributed to our initial negative reactions as readers of the text. We identified and analysed the various categories of teachers that were constituted within the sequence of this news story, noting that they were mostly constructed as simple binary oppositions. By zooming in, we interrogated the details of the text and the reactions they elicited in us as readers. 
We commence examination of the article with a detailed analysis of the Headline "Cash lures to smarten up teaching". We proceed by scrutinising the text in the central box titled "The Clean Out" that contained a number of bulleted points, documenting both our observations regarding the discursive constructions of the textually ordered social world presented in the article, and our critical reflections in response to these constructions. We continue with a more generalised report of our analysis, identifying some of the additional binary oppositions of teacher-types presented in the remainder of this article. We discuss our reactions, and offer some possible implications of these constructions in moulding the reading public's potential ideological understandings of teachers. As part of our analytic method, we use a number of extended metaphors to document our responses and reflections.

\section{Assemblage of 'the catch'}

The headline "Cash lures to smarten up teaching" (Fynes-Clinton 2002) immediately drew our eyes and stimulated our reflections. The phrase assembled, through our commonsense knowledge, the suggestion that some teachers in the system needed to "smarten up". By implication, there were other teachers who were not in such need. The use of the term "lure" simultaneously conjured up notions of entrapment for possibly unwary teachers. "Lures" did double time here for us. This was how 'the catch' began. Instantly it ensnared our interest to continue with the reading. We asked ourselves just how much cash was available, how teachers might obtain it, and what conditions were there for claiming this cash.

Under the headline was a central box with four bulleted points summarising the proposed program. The use of this box worked as a framing device, acting as a visual directive to 
signify that the elements contained therein belonged together (Kress and van Leeuwen 1996, 182-3). Our eyes were certainly enticed (lured) to the bulleted text in the framed central box, entitled "The clean out". The term "clean-out" conjured up associations of clearing out junk or unwanted items. Simultaneously, it also implied that the teachers who were in need of being smartened up were to be caught and cleaned up (or, in this case, cleaned out) - like fish are caught and gutted (to continue the initial metaphor of the "lure"). We wondered where we, as teacher-readers, were positioned in relation to the teacher-categories being set up by the text.

Reading on, the text in the summary box suggested that such a clean-out was not necessarily conceived as merely negative enticement. Teachers were to be offered "a career change program", a phrase that suggested choice rather than compulsion. The lure was certainly looking a distinct possibility for teachers who may or may not have needed to "smarten up". But here again was 'the catch'. The summary box specified particular conditions for the "Career change program". The four bulleted points set up an implied standardised relational pair of mutually exclusive "sub-standard teachers" in contrast to "high level graduates".

\section{Point 1:}

- \$50,000 payments to entice 200 sub-standard teachers to resign from schools and retrain

The \$50,000 dollars looked good! However, in order to obtain the cash, teachers who might be tempted to apply would have to designate themselves as members of the category "sub-standard teachers". Just what was deemed sub-standard was not specified. Such a categorisation certainly would not be viewed positively by the public. As readers 
who were also teacher-practitioners, the lure initially seemed tempting. However, having read the first bulleted point relating to the category sub-standard teacher, we self-selected ourselves out. So, already the category sub-standard teachers who needed to be smartened up and could be lured by cash inducements was assembled in contrast to the implied 'other' kind of teacher with whom we, as readers, included ourselves. The cash looked to be tarnished! However, was that really so? Reading on:

\section{Point 2:}

- "Successful applicants barred from teaching in Queensland state schools again

Bizarrely, to be a member of the sub-standard teacher category, one could claim to be a "successful applicant". Maybe we, as readers, did not have to forgo the $\$ 50,000$ at this point. We could be successful after all! The assemblages of categories became thick with contrasts. The plot thickened!

\section{Point 3:}

- Retrenchments to be voluntary

Choice was implied by this condition. As members of the broader community, we knew that the term retrenchment inferred the notion of excess to need, or held an association with people who were near retirement-age. However, our cultural membership also made us aware that retrenchment tends to be associated with compulsion rather than with choice. The notion of voluntary retrenchment might be read as an oxymoron. However, the cash still was a temptation. Voluntary redundancy may not be such a bad thing after 
all - many baby boomers perhaps dream longingly of early retirement with a cash payout. A career change might not be so dreadful. However, we knew we were doomed when we read the final dot point.

\section{Point 4:}

- High-level university graduates to replace departing teachers

It was at this point that the proposition became untenable for us. The lure had failed! Leaving the teaching profession with cash in hand necessitated us being positioned within the category "sub-standard teacher", in contrast to our position as "high-level university graduates". We reflected. Here was our Catch 22 . We were simultaneously high-level university graduates who were also teachers. But in which category could we claim to belong for the purposes of gaining the cash incentive? It seemed that we could not claim the cash without first acknowledging that we were not high-level graduates. Neither did we see ourselves as being sub-standard. However, the lure of $\$ 50,000$ remained a temptation. It seemed that we had been textually positioned and had positioned ourselves as outside both discursively constructed teacher categories, namely "high-level graduates" and "sub-standard teachers". We were beyond the pale, no less! Our responses were simultaneously angry and amused - comic and tragic (another contrast pair). It seemed from this text that it was possible to be both successful and substandard at the same time. Did that imply the double-negative possibility of being unsuccessful at being sub-standard?

We knew, as social members, that the category "teacher" may conjure up implied connotations of teacher reward through student success. This stood out against the situation of other "sub-standard teachers" who might be rewarded for a lack of success, 
as denoted in this textually constituted contrast pair. The assemblages of teachers were becoming increasingly complex. It seemed that to being barred from teaching in

Queensland schools was the reward for being successful at being sub-standard. What a paradox!

We were encouraged (lured, perhaps!) to read on and consider the continuing descriptors of "sub-standard teachers", as specified in the first five paragraphs of the news article.

\section{Assemblages of sub-standard teachers}

Distinguishable categories of teachers are inter-textually constituted by the use of contrast structures and deictic terms throughout this article. Smith (1990) designates textual strategies that set up binary oppositionals 'contrast structures'. Deictic terms include pronouns and pronominals and, along with temporal and spatial terms such as now, here, there, and then, they work to organise the positions and arrangements of the persons to whom they refer with reference to the 'position' of the speaker or writer. According to Smith $(1990,56)$, "what they [deictic terms] refer to can be identified only when the position of the speaker [or writer] and the context in which they are used is known".

Contrasting categories of "sub standard teachers" and "highly motivated graduates" were drawn in paragraphs 1-12. The category "underperforming teachers" (those who were to be paid to resign) were designated "public school teachers" who were variously portrayed within the initial 12 paragraphs as "tired, unmotivated, burntout or otherwise ineffective" and "disenchanted". Such teachers were further depicted as "not up to (the standard) you would like". The use of "you" here assumes a likeminded readership. However, it seemed that this category of teachers were to be self- 
selecting as those "who really don't want to be in our system" and would need to "apply for the grant" in order to receive the pay-out. The then Education Minister was reported as stating that "we" (presumably members of the State Government) would "do what we can to move them out". A binary opposition of underperforming teachers was contrasted with the "highly motivated graduates" mentioned explicitly in paragraph 4 . We, the analysts, were both bemused and outraged by this simplistic contrasting categorical pair of teachers. Furthermore, the commonsense taken-forgranted proposition that a substantial number of teachers were, in effect, "underperforming", and that there was a need to "re-invigorate teaching in our classrooms" (paragraph 19) contributed towards our increasingly negative reactions to this article.

"Under-performing" could be read as "sub-standard". The enticement to grab the money and run, and to heck with the consequences was there for us as readers. However, the "and never return" had a certain note of finality to it. It did not say leave from the private sector though. So, the category set up here was that state school teachers only were under-performing sufficiently to be required to leave and never return. Paradoxically, even if state school teachers were under-performing, it seemed that there was nothing to stop them joining the private sector. Was it this possible movement that was implied through the use of the term "career-change," as specified in the boxed topic sentence? We pondered on how private school teachers might have read this. The category of possibly sub-standard state school teachers in contrast to the implied probably high-performing private school teachers was textually assembled here. As state school teachers ourselves, we were provoked.

The contrasting category of state versus private school teachers was confirmed in paragraph 2, where "public school teachers" were named explicitly. We reflected from 
our own position as public (state) school teachers. It seemed that teachers, such as us, might possibly be enticed to be bought out of the state school system. It appeared that private school teachers would not have that option. Did that mean that private school teachers could not be bought? Inter-textual connotations of thirty pieces of silver were conjured up in our minds, constructing yet another contrasting standardised relational pair. Once again our own positioning was made problematic. The need to self-select as one or other of these contrasting teacher categories remained challenging. To self-select as one entitled to the cash incentive was to acknowledge that we were "sub-standard"; but to self-select out of this category removed us from the possibility of gaining the cash lure. This was yet another 'Catch 22' situation.

It was at this point that we stopped viewing the article as humorous and we became increasingly offended. We reflected on why this was so. It looked to us to be a case of "out with the old and in with the new". The use of "highly-motivated" in paragraph 4, as the State Education Minister had been reported as saying in paragraph 3, set up another binary opposition in contrast to a "sub-standard" teacher. According to this, an implied but un-named category of under-motivated teachers would be replaced by such "highly motivated graduates". We, the readers, realised that part of our anger stemmed from the fact that the ambiguous but contrasting categorisations of teachers had not been problematised in the text to this point. The text suggested that all new graduate teachers were always highly motivated, whereas their implied binary opposite, long serving teachers, were not. Our own experiences as members of the teaching profession told us that not all new graduates were, in fact, 'highly motivated'. However, this was not indicated in the category "graduate" assembled here.

Paragraph 5 broke down the sub-standard teacher category still further. The descriptor "underperforming" acknowledged the possibility that not all applicants for the 
"cash lure" would be successful. The irony was that to be a successful candidate for the cash incentive, a teacher had to be underperforming. We questioned into which category of teacher we might position ourselves now, and found the placement task to be difficult, if not impossible. As readers, we had the choice of either reading ourselves out or in to the "sub-standard teacher" category. The ambiguities of having to self-categorise became overwhelming. We were reminded of Doc Daneeka's description of Catch 22, and Yossarian's subsequent response to this, describing it as "some catch" (Heller 1955, 54).

The simplistic and negative construction of "underperforming teachers" was complicated in paragraphs 5 to 7 with the insertion of the Teachers' Union perspective, as reportedly stated by the "teachers' union vice president". His concern was in relation to funding schools, and he asked for a guarantee that "school budgets will not be raided". Furthermore, he was concerned that " 200 teachers (out of 36,000 members) is a drop in the ocean". This statement seemed to perpetuate the possibility that there may have been numbers in excess of the specified 200 teachers already within the system who were underperforming and wanting to self-select themselves as "sub-standard" and, therefore, as candidates for the cash handout. Furthermore, the Union Vice President stated that the union's concern was not in relation to the position of the underperforming teachers who were able to collect the handout and leave, but rather that the Union was "worried about ... class sizes and behaviour management issues", and that "this package is doing nothing to support those teachers who are left in the system". We, as union members, were incensed that the Union Vice President seemed to be colluding in the notion that the state schools were possibly full of incompetent teachers who were in need of encouragement to leave. However, the Union spokesperson acknowledged the possibility that educational structural arrangements might be contributing partially towards the creation of "disenchanted" teachers. He stated that "this package is doing nothing to support those 
teachers who are left in the system". We understood this as a request for the Government to provide funds to improve the situation of practising teachers. The then State Minister for Education partially addressed this concern when she was reported as saying, "the Government had set a clear agenda on education reform and this plan was designed to 'reinvigorate teaching in our classrooms"' (paragraph 13). However, both this statement and the position adopted by the Teachers' Union Vice President did nothing to counteract the continuing deficit view of teachers, particularly in regard to "permanent employees with at least 10 years teaching service" - that is, of experienced teachers, constructed within this article.

\section{The selection process}

Teachers were to self-select to apply for the cash payment: "Teachers themselves will make the decision about whether they put themselves forward", fulfilling "a range of unspecified criteria". However, the decision regarding who would be granted the $\$ 50,000$ was to be made by "A South Australian consultancy, which has managed similar programs for education departments in other states". This suggests general government distrust in the professionalism of teachers as sufficiently competent to undertake the process of selection themselves - another deficit model. This factor further illustrates research findings suggesting that teachers continue to be de-professionalised, and that decisions increasingly are being made by government agencies with little, if any, input from teachers themselves (Hargreaves 1997). Indeed, similar to Thomas (2003), we found this article provided further evidence that, when teacher quality is under question, the media construct public discourses that diminish the authority of teachers to speak, or have a voice in decisions about education policy. 
The article concluded by presenting a response from the opposition party leader at that time. He reportedly viewed the payout as paltry, signified by naming it a "bronze handshake". He then further strengthened the continuing discursively constructed deficit view of state school teachers when he stated that "if 2000 staff applied for the 'bronze handshake', 1800 sub-standard teachers would remain in the system". We were outraged! As teacher practitioners, we felt disempowered and insulted by these negative public discourses regarding members of our profession. We were upset that this dominant deficit model of older experienced teachers, particularly those in state schools, would work to further increase and perpetuate negative public opinion regarding state schooling practices. It was at this stage that we decided that we would not conspire with such negative public discursive constructions of long serving teachers by applying for the grant and leaving the profession silently, cash in hand, however tempting. Rather, we decided to expose and challenge the continuing moral panic regarding teacher quality perpetuated by this and similar news articles.

By zooming in to critically analyse and reflect on the effects of the news article, we have shown some operational structures, practices and devices that informed this text (Jalbert 1999, xv). The news article actively constructs a particular social order, privileging the highly motivated [beginning teacher] graduates" over experienced but "disenchanted teachers". We continued analysis by zooming out to consider the possible impact of this media discourse on the formation of public opinion regarding public school teachers and teaching.

\section{Zooming out - media discourses and public opinion}

Media texts are embedded in the normative structures of everyday life (Thomas 2006), and organise social relations. They are, then, political in that they work to actively 
construct the relations of ruling of the social world of which they are a part. Smith defines the relations of ruling as "that extraordinary yet orderly complex of relations that are textually mediated, that connect us across space and time and organize our everyday lives - the corporations, government bureaucracies, ... mass media, and the complex or relations that interconnect them" $(2005,10)$. According to Smith (1990, 2005), social members are ruled in forms of organisation that are vested in and mediated by dominant public discourses that become largely invisible. Zooming out to analyse dominant public textual discourses, such as the news article under examination in this paper, can reveal the largely invisible relations of ruling that work to accomplish the social relations in which media texts occur, privileging some, and disempowering other social members.

So, what are the political implications of such media-constructed deficit views of state school teachers and, by implication, state schools and state educational practices, and how do they work to produce and reproduce the invisible relations of ruling of which they are a part? Zooming out enabled us to critically engage with and think about the public discourses constituted within this particular news article in relation to current social trends. In this way we could reflect on the potential impact of the largely negative and sometimes puzzling textual constructions of teachers identified here, and consider their possible impact on public opinion regarding teacher quality, student standards, schools and schooling practices.

As discussed earlier, media articles have the potential to shape public opinion about education and schooling through dominant discourses. Zooming out revealed three main dominant discourses, as described below.

The first dominant discourse constructed in this article is that of ageism. Bearing in mind that information presented in a Department of Education and Science 
(DEST) Report in 2003 revealed that over the 15 years to 2001, the median age of the teaching population had risen from 34 to 43 years, and the percentage of teachers over the age of 45 years rose from 17 to 44 per cent, it might not be surprising to find such a discourse. In the news article that is the focus of this paper, teachers were constructed in the form of an implied standardised relational pair of "sub-standard teachers" with "at least 10 years teaching experience" in contrast to a younger group of "highly motivated graduates". Increasing numbers of older teachers, and ageist textual constructions evidenced in public discourses such as the one identified here may well work to convince the reading public of the need for a "plan to "reinvigorate teaching in our classrooms", thereby reflecting and possibly strengthening contemporary dominant western views regarding the positives associated with youth in contrast to the negatives associated with age and/or experience. As such, the article certainly privileged new, probably younger, teachers at the expense of "other" experienced and probably older teachers, many of whom were deemed to be sub standard.

Furthermore, in most of the western world there is an existing shortage of teachers, particularly those with expertise in Mathematics and Science (School of Education, The University of Queensland 2004). Negative notions of teachers in general certainly will not value-add to the profession, or encourage high achieving school leavers to opt for teaching as their future preferred career option. With regard to the bigger picture situation, discourses that continue a preference for youth must, by implication, strengthen negative commonsense views regarding the increasingly aging population in Australia (Australian Bureau of Statistics [ABS] 2008). Such ageist public discourses may well contribute towards an increased acceptability of ageist workplace practices. 
In addition to the discourse of ageism described above, this news article also constructs a second dominant discourse, that of gender. ABS statistics reveal that the proportion of full time teaching equivalent (FTE) female teaching staff continues to rise. In 1998, 65\% of all FTE teachers were female, whereas in 2008 this percentage had risen to $69 \%$ of all FTE teachers being female (ABS 2008). Increasing numbers of aging female teachers and negative public discursive constructions of long serving teachers such as those illuminated in this news article may well work as a disincentive for males, particularly younger males who might be considering entering the teaching profession. Such public discourses may perhaps contribute towards the current and continuing dearth of males entering the teaching profession (ABS 2008).

The third dominant discourse constructed in the focus article is one of socioeconomic status in the form of the binary of state (public) versus private schooling. This news article presented the case that state schools contained at least 200 substandard teachers who needed to be persuaded to resign from the profession in 2002. Private schools were the implied "other". There was no explicit acknowledgement or reference to the situation that private schools also may have contained "underperforming" teachers. Australian population statistics highlight an increasing number of parents opting to send their children to private schools rather than to state schools (ABS 2008). Contemporary neo-liberal government educational policies and funding arrangements support this population trend, both at state and federal level. Continuing public media discourses regarding state schools as being in crisis certainly do nothing to counteract this movement. The potential long-term result of rising numbers of parents opting for private rather than state schools for their children (ABS 2008) creates an inevitable further polarisation between the state and public education system, with state schools being further disadvantaged. The increased focus on the 
importance of "parental choice", the increased privatisation of western schooling systems, and publication of tables of student learning outcomes, such as those highlighted in the recently established MySchool website in Australia (Australian Curriculum, Assessment and Reporting Authority [ACARA] 2010), have encouraged more privileged parents to use the opportunities offered by the current educational quasi-market to their advantage (Ball 2008). On the other hand, parents who might be designated "underprivileged" or from lower socio-economic status (SES) backgrounds may not have equal or similar schooling choices. Highlighting such factors can contribute towards understanding social trends. Illuminating such trends can expose social justice issues in relation to the state versus private school situation. Analysis of this particular news article works, in part, to do this.

Having described the three dominant discourses that were constituted discursively in this text, as presented above, it seems logical to argue that such constructions may well work to perpetuate continuing views of schools as being in crisis and of teachers not being up to scratch, thereby strengthening and perpetuating continuing deficit public views of teachers and teaching.

Since publication of the news article that is the focus of this paper, numerous media articles have appeared regarding teacher quality and student standards in Queensland. These items appear as largely media-driven campaigns focussing on news stories regarding education that dominate media channels for varying, but often very concentrated, periods of time, in the forms of news flashes, feature articles, editorial comment and letters to the editor. More recently, news articles have expressed concerns regarding the quality of new teacher graduates rather than of long-serving experienced teachers. So, for example, in 2006, the Courier Mail presented a series of news items that constructed negative images of pre-service and beginning teachers, 
fore-grounding concerns regarding the quality of the new teachers. For instance, a front page lead article with the headline "Teachers come from the bottom of the class" (Fynes-Clinton 2006) was followed by a second article on page 4 (FynesClinton and Livingstone 2006) with the headline "Teacher standards slipping" that commenced with the text "Some of Queensland's future teachers are being drawn from among the bottom third of school leavers seeking tertiary places...”. In that same issue there was an editorial item headed "Time to face teaching problem" (Courier Mail 2006, 26). On the following day (23 March), Livingstone (2006, 7) presented an article headed "Teaching to smarten up", and this issue also included three letters to the editor that appeared under the header "Scoring teachers" that expressed concerns regarding low university entry score requirements for new teachers into the profession, and a column of blog entries next to them also focussing on teacher entry standards headed “Pass mark?" (Courier Mail 2006, 29). This and similar media campaigns cannot work other than contribute towards increased negative public opinion in the form of a crisis mentality regarding teacher quality and school standards (Thomas 2006).

Perhaps it is not surprising that the long term cumulative effect of regular exposure of the reading public to repeated suggestions that teachers are not satisfactory is a loss of confidence in the quality and professionalism of teachers. This loss of confidence may well be contributing towards the reduced number of applicants for the teacher education programs at universities across the nation (Commonwealth of Australia 2007), as well as to the high attrition rate of teachers leaving the profession early. Reasons for early leaving or retirement from the profession are presently under study, as reported in the Courier Mail in an article with the headline "Lesson in exodus of teachers" that commenced with the words: "A teaching skills crisis looms 
as mature-age workers desert the classroom ...”. In this article it was reported that, “interviews with recently retired high school teachers discovered many left work before they could afford it because they did not feel supported by the education bureaucracy $(2008,3)$. The article suggested that numbers of experienced teachers have, indeed, been taking the opportunity to leave the profession early. As such, some of these teachers may well have been lured by the promises of cash incentives, such as the Education Queensland's \$50,000 payout scheme for "burnt-out" teachers.

Although it must here be noted that "good news" stories about schools and teachers in Australia are not unknown, news articles portraying teachers less than favourably continue to appear regularly in high status news outlets. We support Snyder's view that "it makes no sense to continually undermine those who are charged with the significant social responsibility of educating the next generation of citizens" $(2008,222)$, arguing that that negativity regarding teachers and teaching presented in public discourses work in ways that can further undermine public confidence regarding education and schools across the nation. We suggest that the media consider the potentially damaging long-term effects of their war on teachers, and to change the 'teacher crisis' discourse to one of 'the importance of good teachers' for improved schooling practices.

To date, there have been four rounds of offers of a $\$ 50,000$ payout to "underperforming" state school teachers in Queensland. News of the most recent Queensland payout scheme appeared in an article in the Courier Mail published on 2 October 2007 under the headline "Make way for new blood: Burn-out bonus for 360 teachers" (Wenham 2007). It has been of interest to follow the progress of a number of ex school teacher colleagues of our acquaintance who applied for and were accepted for "voluntary retrenchments" from the Queensland state education system since the 
first round of payout offers in 2002. Some have moved away from Queensland and are currently employed as teachers in both state and private schools in other Australian States or Territories. Some have moved overseas. Some have started up private consultancy businesses, some of these maintaining links with an Education system. And a few have used their cash payouts to fund early retirement packages. To our knowledge, however, very few have removed themselves entirely from the world of education.

\section{Summary and conclusion}

In summary, our first reading of the news article that was the initial focus of this paper revealed what appeared to be a simple textually constructed binary opposition of new, "highly motivated graduates" in contrast to experienced but "disenchanted teachers" (Fynes-Clinton 2002). However, zooming in and zooming out of the news article revealed that more complex implied contradictory versions of teachers were assembled within the text, resulting in us being unable to read ourselves into any of them comfortably. Using these reflective practices to examine this news article has enabled us to explore, productively, issues of personal, professional and social significance.

This article, along with other negative articles about teacher quality that appear regularly in the media, must inevitably contribute to continuing and pervasive public deficit views of teachers and teaching. There is no doubt that teachers and the teaching profession would benefit greatly from a more positive press. As such, we conclude this paper by arguing the need for "commonsense" public discourses to be further critiqued and publicised to counter-act the further development of public opinion and moral panic regarding declining teacher quality and standards, and of public schools as being in crisis. 


\section{Notes on contributors}

Jayne Keogh is a lecturer at the School of Education and Professional Studies at Griffith University (Gold Coast Campus), Australia. She has research expertise in institutional ethnography, ethnomethodology, conversation and membership categorisation analysis.

Barbara Garrick is a lecturer at the School of Education and Professional Studies at Griffith University (Gold Coast Campus), Australia. She has research expertise in educational policy and practice.

\section{References}

Australian Curriculum, Assessment and Reporting Authority (ACARA). 2010. Retrieved on 21 December 2010 from http://www.myschool.edu.au/AboutUs.aspx.

Australian Department of Education, Science and Training (DEST). 2003. Australia's Teachers: Australia's Future. Retrieved on 21 December 2010 from http://www.dest.gov.au/NR/rdonlyres/097DAD07-3C82-47B3-9BF325283759E627/1657/Data_Analysis.pdf.

Australian Department of Employment, Education, Training and Youth Affairs (DEETYA). 2000. Teachers for the $21^{\text {st }}$ century: Making the difference. Canberra: Commonwealth of Australia.

Australian Bureau of Statistics (ABS). 2008. Retrieved on 21 December 2010 from http://www.ausstats.abs.gov.au/Ausstats/subscriber.nsf/0/3A0FDBBD4011266E CA25732F001C6154/\$File/4102.0\%20- 
\%20Australian\%20Social\%20Trends\%20-

\%20Education\%20and\%20Training\%20-\%202007.xls.

Australian Parliamentary House of Representatives Standing Committee on Education and Vocational Training. 2007. Top of the class: Report on the Inquiry into Teacher Education. Canberra: Commonwealth of Australia.

Baker, C. 2000. Locating culture in action: membership categorisation in texts and talk. In Culture and text: Discourse and methodology in social research and cultural studies, ed. A. Lee and C. Poynton, 99-113. St Leonards, NSW, Australia: Allen \& Unwin.

Ball, S.J. 2008. The education debate. Bristol, UK: Policy Press.

Cohen, S. 1980. Folk devils and moral panics: The creation of the Mods and Rockers. New York: St Martin's Press.

Courier Mail. 2006. March 22.

Courier Mail. 2008. June 21-22.

Dawkins, J. 1988. Quality of teaching an issue for all. Canberra: Australian Government Publishing Services.

Fairclough, N. 1992. Discourse and social change. Cambridge: Polity.

Fairclough, N. 1995. Media discourse. London/New York/Sydney/Auckland: Arnold. Fynes-Clinton, M. 2002. Cash lures to smarten up teaching. The Courier Mail, April 25,4 .

Fynes-Clinton, M. 2006. Teachers come from bottom of the class. Courier Mail, March 22, 1-4.

Fynes-Clinton, M., and T. Livingstone. 2006. Teacher standards slipping. Courier Mail, March 22, 1. 
Gee, J.P. 1999. An Introduction to discourse analysis theory and method. 2nd ed. London: Taylor \& Francis.

Habermas, J. 1996. The public sphere. In Media studies: A reader, ed. P. Marris and S. Thornham, 55-9. Edinburgh: Edinburgh University Press.

Hargreaves, A. 1997. Cultures of teaching and educational change. In International handbook of teachers and teaching, ed. B.J. Biddle, T.L. Good, and I.F. Goodson, 1297-319. Dordrecht, The Netherlands: Kluwer Academic.

Heller, J. 1955. Catch 22. London: Corgi Books.

Heritage, J. 1984. Garfinkel and ethnomethodology. Cambridge: Polity Press.

Hester, S., and P. Eglin. 1997. Studies in ethnomethodology and conversation analysis. Washington, DC: International Institute for Ethnomethodology and Conversation Analysis \& University Press of America.

Ivanic, R. 1994. I is for interpersonal: Discoursal construction of writer identities and the teaching of writing. Linguistics and Education 6, no. 1: 3-15.

Jalbert, P.L. 1999. Media studies: Ethnomethodological approaches. Lanham, MD: University Press of America.

Jayyusi, L. 1984. Categorisation and the moral order. Boston, MA: Routledge \& Kegan Paul.

Johnson, G. 2001. Understanding textual intervention: From reading to writing practices. English in Australia 123: 47-55.

Keogh, J. 1999. The role of texts and talk in mediating relations between schools and homes. Unpublished $\mathrm{PhD}$ thesis, Griffith University, Brisbane.

Kress, G., and T. van Leeuwen. 1996. Reading images: The grammar of visual design. London: Routledge. 
Lewis, S. 1991. A classroom revolution. Australian Financial Review, February 11, $10-11$.

Livingstone, T. 2006. Teaching to smarten up. Courier Mail, March 23, 7.

Ministerial Advisory Council on the Quality of Teaching (MACQT). 1997. Raising the standing of teachers and teaching. Sydney: MACQT. Retrieved on 21 December 2010 from http://www.det.nsw.edu.au/reviews/macqt/standa.htm (accessed August 3, 2004).

McHoul, A. 1982. Telling how texts talk: Essays on reading and ethnomethodology. London: Routledge \& Kegan Paul.

MySchool website. Retrieved on 21 December 2010 from http://www.myschool.edu.au/.

Risner, D. 2002. Motion and marketing in reflective practice: Artefacts, autobiographical narrative and sexuality. Reflective Practice 3, no. 1: 5-20.

School of Education, The University of Queensland. 2004. EDUC3079 Course profile: Teachers' work in contemporary contexts. Brisbane: The University of Queensland.

Schools Council. 1990. Australia's teachers: An agenda for the next decade. Canberra: Australian Government Publishing Service.

Silverman, D. 1993. Interpreting qualitative data: Methods for analysing talk, text and interaction. London: Sage.

Smith, D.E. 1990. Texts, facts and femininity: Exploring the relations of ruling. London/New York: Routledge.

Smith, D.E. 2005. Institutional ethnography: A sociology for people. Lanham, MD/New York/Toronto/Oxford: Altamira Press. 
Snyder, I. 2008. The literacy wars: Why teaching children to read and write is a battleground in Australia. Crows Nest, NSW: Allen \& Unwin.

Stockhausen, L., and A. Kawashima. 2002. The introduction of reflective practice to Japanese nurses. Reflective Practice 3, no. 1: 117-30.

Thomas, S. 2002. Silence of the lambs. Journal of Curriculum Theorising 18, no. 3 : 89-102.

Thomas, S. 2003. The trouble with our schools: A media construction of public discourses on Queensland schools. Discourse 24, no. 1: 19-33.

Thomas, S. 2006. Education policy in the media: Public discourses on education. Teneriffe: Post Pressed.

Thomas, S. 2008. Leading for quality: Questions about quality and leadership in Australia. Journal of Education Policy 23, no. 3: 323-34.

Thomas, S. 2009. Newspapers on education policy: Constructing an authoritative public voice on education. In Media, policy and interaction, ed. R. Fitzgerald and W. Housley, 205-23. London: Ashgate Publishing.

Wenham, M. 2007. Make way for new blood: Burnout bonus for 360 teachers. Courier Mail, October 8, 5. 